\title{
The Study of Online Lecturing Implementation in Improving Skills of Early Childhood Teacher in Handling Children with Special Needs
}

\author{
Ana Rafikayati \\ Special Education Department \\ PGRI Adi Buana Surabaya University \\ Surabaya, Indonesia \\ ana.rafikayati@gmail.com
}

\author{
Lutfi Isni Badiah, Mudhar \\ Guidance and Counseling Department \\ PGRI Adi Buana Surabaya University \\ Surabaya, Indonesia \\ lutfiisnibadiah@gmail.com,mudhar.bps@gmail.com
}

\begin{abstract}
The purpose of this research was to describe the implementation of online lecturing in improving skills of early childhood teacher in handling children with special needs in Sidoarjo. This research used qualitative approach with descriptive qualitative type. Research subject in this study was 20 early childhood teachers that consisted of 14 teachers of Peek a Boo School and 6 teachers of Permata Bunda School Sidoarjo. The collecting data techniques in this study were interview, observation and documentation. Data analysis techniques used follow analysis techniques of Miles Huberman which the steps are data reduction, data display and verification. Result shown that e-lecturing implementation was divided into 3 activities, namely (1) preparation, (2) implementation, and (3) evaluation. The activities carried out in the preparation phase are 1) coordinating with schools partner, 2) preparing training materials, and 3) making online classes. While the implementation phase includes 2 activities, namely 1) training, and 2) accompaniment. The training was carried out in two ways, namely (a) face-to-face training at partner schools and (b) online training. While the implementation of accompanimentis carried out by assisting the teacher during the implementation of the identification, assessment and making Individualizes Education Program (IEP). In the evaluation phase the team evaluated whether online lecturing training were effective in improving teachers' understanding and skills in handling children with special needs, especially in the identification, assessment and making IEP.
\end{abstract}

Keywords- Online Lecturing, Skills in Handling Children with Special Needs.

\section{INTRODUCTION}

Based on world issues about education for all, today Indonesia is starting to develop an inclusive education system. Inclusive education according to Minister of National Education Regulation No. 70 of 2009 is an educational system that provides opportunities for all students who have abnormalities and has the potential for intelligence and / or special talents to attend education or learning in an educational environment in regular schools together with students in general or commonly known as regular students.
In line with the enactment of Minister of National Education Regulation No. 70 of 2009, school from various levels began to become inclusive schools, as well as Early Childhood Education. Early Childhood Education as the most basic and earliest education, is now starting to open itself to inclusive early childhood education, namely early childhood education institutions that accept children with special needs to study with regular students.

The increasing number of inclusive early childhood education has not been accompanied by an adequate understanding of school attributes in this case educators (early childhood education teachers are graduated from bachelor of early childhood education). They did not study deeply about children with special needs. Therefore, many early childhood education teachers are confused and have difficulties in handling children with special needs. This is consistent with the results of [1] in the city of Malang. Of the 45 early childhood education teachers, it is known that $90 \%$ of teachers do not have instruments to detect children with special needs, $70 \%$ of teachers do not have experts to help in early detection of children with special needs, $70 \%$ of teachers do not know how to intervene in children with special needs, $60 \%$ do not know how to do an assessment or make early detection on children with special needs and $60 \%$ do not know in detail the characteristics of children with special needs.

Results that are not much different are also found in Peek a Boo School and Permata Bunda School Sidoarjo. In accordance with the results of the preliminary study carried out by the team, it was obtained data that $95 \%$ of difficulties in identifying children with special needs and $98 \%$ had difficulty in providing appropriate services. Based on these data, it can be concluded that the majority of teachers at Peek a Boo early childhood school and Permata Bunda School have difficulty handling children with special needs in their schools.

Peek a Boo School was located on Jl. Delta Raya Utara No.66, Waru, Sidoarjo Regency, East Java. The school had 117 students and 26 teachers. Despite not declaring themselves as an inclusive school, this school had received children with special needs to study together with other students. The number 
of children with special needs for the 2016/2017 school year in Peek a Boo School was estimated at 14 children. Types of specificity include down syndrome, ADHD and slow learner. Even so, the number and type were still tentative because the school was still in doubt on the results of the identification. This is because identification was only carried out by classroom teachers who actually only graduated from bachelor of early childhood education (not special education) and have never received training in children with special needs or inclusive education.

Similar things were also found in Permata Bunda School. Permata Bunda School was located at Jl. Cendrawasih No.22C Kepo Betro Sedati, Sidoarjo Regency, East Java with 23 students and 4 teachers. The number of children with special needs for the 2016/2017 school year was 6 types with the type of slow learner and hyperactivity. As with the Peek a Boo School, Permata Bunda felt less confident in identifying children with special needs because the schools did not have the tools / instruments that could be used to recruit children with special needs.

Based on the field findings, it was found that most of the teachers at Peek a Boo School and Permata Bunda did not understand children with special needs and how to handle them. Whereas for children with special needs, early age is a critical period. Early age is a golden age. [2]. The period in which children will easily accept, follow, see and hear everything so that all information is stored in a child's longterm memory. Therefore, early childhood education must pay attention to all its potential to be developed as optimally as possible. [3] added that the right intervention or treatment at an early age can prevent development problems from being widespread, profound and have a negative impact on other aspects of development.

If during this critical period children with special needs is not given proper treatment, then their delay will be even greater than their children. For example, children with hearing impairment. If the child does not get intervention at an early age, it will have an impact on the low development of language, reading, academic achievement, social, emotional, child behavior, verbal intelligence, self-development and some psychological diagnoses [4].

In conducting early intervention in children with special needs, cooperation from various multidisciplinary is needed. Teachers as one of the disciplinary elements are expected to play an important role in the implementation of interventions for children with special needs. This is consistent with the opinion of [5] which states that in the educational intervention model, teachers or pedagogues must carry out their functions and roles as the spearhead and coordinator of the overall intervention program implemented.

Based on this exposure, the teacher must have an understanding and skills in handling children with special needs so that educational interventions for children with special needs can succeed and children can develop optimally. Peek a Boo School and Permata Bunda School as a school that serves children with special needs are expected to provide education services to children with special needs. To achieve this, teachers as the main element in schools must improve their understanding and skills in handling children with special needs so that they can provide appropriate education services for children with special needs in their schools. In accordance with these problems, it is necessary to do it.

In accordance with these problems, it is necessary to conduct training on handling children with special needs. Teacher training is considered effective in improving teacher skills in handling children with special needs because with training, teachers are given knowledge about children with special needs and trained in how to handle children with special needs correctly. Training in children with special needs handling. Teacher training is considered effective in improving teacher skills in handling children with special needs because with training, teachers are given knowledge about children with special needs and trained in how to handle children with special needs correctly.

The purpose of this research was to describe the implementation of online lecturing in improving skills of early childhood teacher in handling children with special needs in Sidoarjo.

\section{METHOD}

This research used qualitative approach with descriptive qualitative type. Research subject in this study was 20 early childhood teachers that consisted of 14 teachers of Peek a Boo School and 6 teachers of Permata Bunda School Sidoarjo. The collecting data techniques in this study were interview, observation and documentation. Data analysis techniques used follow the analysis technique of Miles Huberman of which the steps are data reduction, data display and verification.

\section{RESUlT AND DISCUSSION}

E-lecturing implementation was divided into 3 activities, namely (1) preparation, (2) implementation, and (3) evaluation. E-lecturing implementation is described as follows.

\section{A. Preparation Phase \\ 1) Coordinating with Schools Partner}

In this stage, team coordinated with partner schools namely Peek a Boo school and PermataBunda School Sidoarjo. The coordination that was carried out included the schedule for the implementation of training and assistance, the place of implementation and the supporting tools needed during training. The coordination implementation was carried out at Peek a Boo School on $23^{\text {rd }}$ of April 2018 and Permata Bunda School on $24^{\text {th }}$ of April 2018

\section{2) Preparing Training Materials}

After coordinating with schools partner, team designed the material to be given during the training. The materials given were 1) identification of children with special needs, 2) assessment of children with special needs, and 3) IEP for children with special needs. The materials compiled were: 1) handout 3 material, 2) media power point 3 material, 3) 
instrument identification of children with special needs, 4) sample assessment results, and 5) sample of IEP.

After all the materials were ready, then the team prepared the tools, materials and media needed during the training. In training in the online setting the team needed a laptop, smart phone and internet network. As for face-to-face meetings, the required media included: LCD projectors, stationery, handy camps, learning media for simulation, etc.

\section{3) Making Online Classes}

After the training materials were created, the team then created a class in google classroom. This class was followed by partner teachers as students. In this class the team distributed materials so that they could be accessed by partner teachers online anywhere and anytime. The online class display can be seen in Figure 1 as follows.

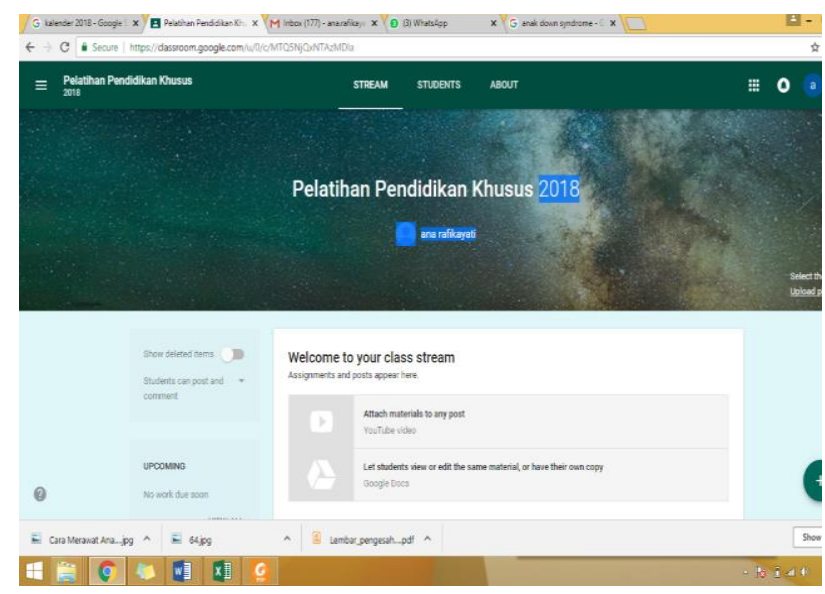

Fig. 1. Online Classes

\section{B. Implementation Phase}

\section{1) Face-to-Face Training}

The training consisted of 3 materials, namely (1) identification of children with special needs, (2) assessment of children with special needs, and (3) preparation of IEP. The children with special needs identification material was material that aimed to enable the teacher to have an understanding and skills in identifying children with special needs. In this training participants in this case teachers were given instruments to detect various types of children with special needs including blind, deaf, mentally disabled, disabled, slow learning, gifted, communication disorders, ADHD, and autism. After that, training participants were trained to be able to practice the identifying instrument.

The children with special needs assessment material was material that aimed to enable teachers to collect information about children with special needs which included strengths, weaknesses, characteristics of children with special needs. The assessment results were then used as a basis for the preparation of the IEP. At this stage of training, teachers were trained to recognize the characteristics of each need. This was because each specificity had its own character. Teachers were taught to use multi methods in gathering information about children so that the resulting data was more valid. Teachers were trained in various methods in conducting children with special needs assessments. By gathering these various information, it is hoped that the teacher can compile the IEP according to the child's needs and abilities.

The material for the preparation of the IEP was the material that aimed to enable the teacher to compile the IEP according to the needs of each child. With this training, it was expected that the teacher can measure abilities that have / have not been mastered by the child, knows the strengths and weaknesses of the child and then develops a service / therapy program that was appropriate for the child. The IEP components included: 1) abilities that had been mastered by children, 2) abilities that had not been mastered by children, 3) advantages, 4) lacked of children. Based on the profile, a service planning program is needed for children, including: 5) program objectives, 6) material, 7) methods, 8) media and 9) evaluation. With this training, it is expected that the teacher can measure abilities that have / have not been mastered by the child, know the strengths and weaknesses of the child and then develop a service / therapy program that is appropriate for the child.

Each training material was held for 3 meetings which were divided into 2 face-to-face meetings (@4 x 60 minutes), and 1 live streaming meeting (@ 1 x 60 minutes) plus communication through class discussions in the google classroom done freely for 24 hours. While the implementation of mentoring was carried out by assisting the teacher during the implementation of the identification, assessment and IEP practice. This was done so that teachers could better understand the process and method of identification, assessment and IEP appropriately

\section{2) Online Training}

Online lecturing was conducted where trainers and trainees did not need to meet face-to-face. Enough training was carried out online through computers, laptops or Mobile Smart Phones that were connected to the internet. Based on the characteristics of the teacher and also the school, the data obtained were that the majority of teachers were classified as young and very technologically literate. Based on these problems, the solution offered is teacher training about skills in handling children with special needs delivered online (training based on online lecturing). This was done because online lecturing-based training was supported by the availability of an adequate internet network and every teacher had a Smart Phone.

For the sake of training effectiveness, the teacher had training materials that contain things learned during the training. Through this online lecturing, trainees could access them through the google class room that had been created by the team. Besides downloading material, the google class room also regulated the circulation of tasks during training.

The online training process was carried out through a hangout application that collaborated with YouTube. Through this application, trainees could watch lectures both online and off-line. The results of the training were stored on YouTube automatically. Thus trainees could access training sessions done at any time. This description of the online training process can be seen in Figures 2 and 3 as follows. 


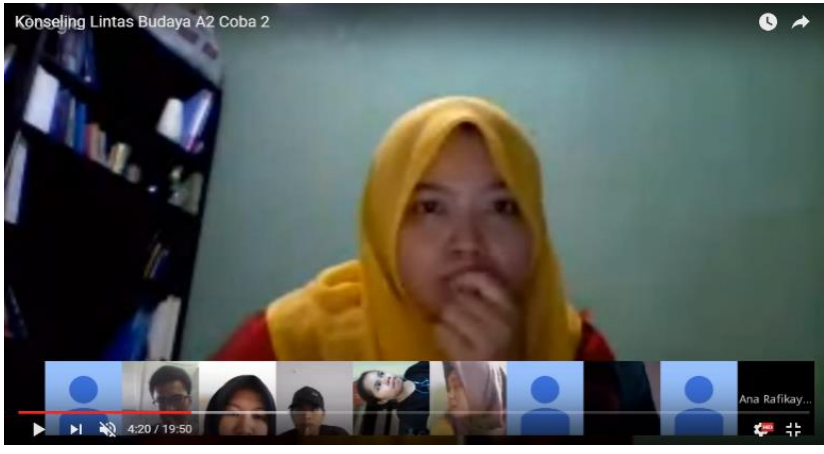

Fig. 2. Teacher Join in Live Streaming Class

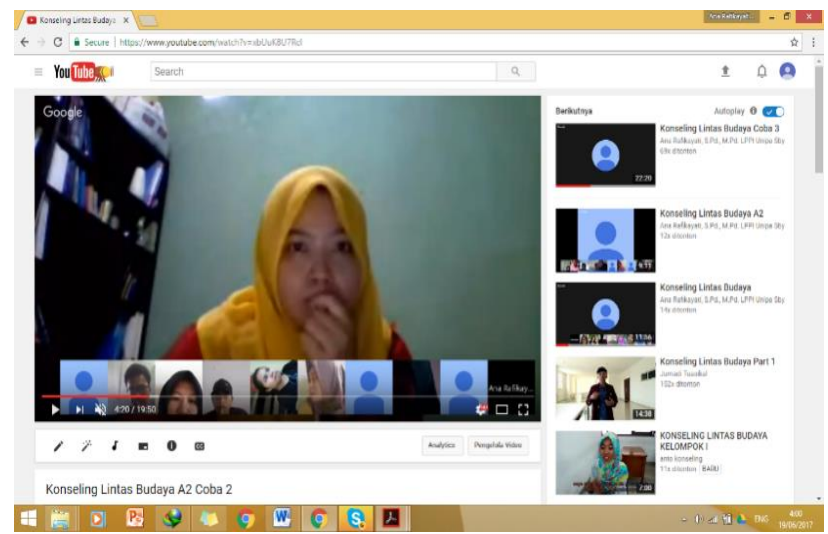

Fig. 3. Training Process can be Seen in Youtube

The media used were Auto Play application that can combine text, audio, and video with an interactive display. When face-to-face training was carried out, the media were displayed through an LCD projector, while when the training ran online, the media were displayed with a hangout application through the help of sharing screen. The description of the media used during training can be seen in Figure 4 as follows.

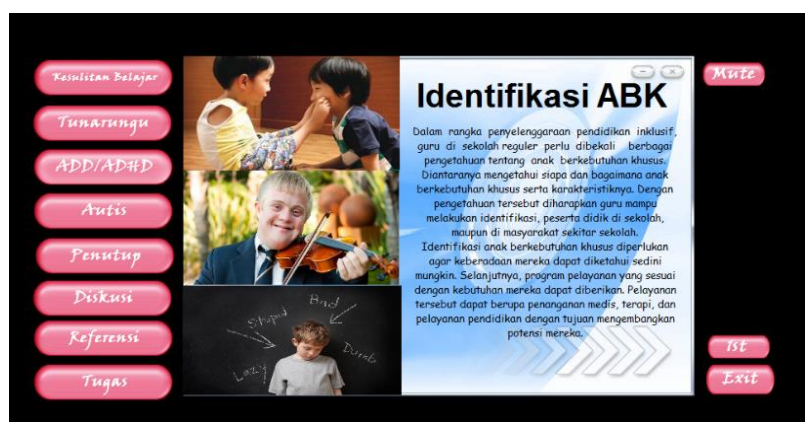

Fig. 4. Training Media Uses Auto Play

\section{3) Accompaniment}

The implementation of accompaniment was carried out by assisting the teacher during the implementation of the identification, assessment and PPI practice. This was done so that teachers could better understand the process and method of identification, assessment and IEP appropriately.

\section{Evaluation phase}

In the evaluation phase the team evaluated a series of activities carried out. The team evaluated whether Online lecturing-based training and mentoring provided were effective in improving teachers' understanding and skills in handling children with special needs, especially in the identification, assessment and preparation of IEP. If the training objectives have not been achieved, it is necessary to do an analysis to see which needs to be improved and find solutions to existing constraints.

\section{CONCLUSION}

E-lecturing implementation was divided into 3 activities, namely (1) preparation, (2) implementation, and (3) evaluation. The activities carried out in the preparation phase were 1) coordinating with schools partner, 2) preparing training materials, and 3) making online classes. While the implementation phase included 2 activities, namely 1) training, and 2) accompaniment. The training was carried out in two ways, namely (a) face-to-face training at partner schools and (b) online training. While the implementation of accompaniment was carried out by assisting the teacher in the process of identification, assessment and making IEP. In the evaluation phase the team evaluated whether online lecturing training were effective in improving teachers' understanding and skills in handling children with special needs, especially in the identification, assessment and making IEP.

\section{REFERENCES}

[1] C. Suryaningrum, T. M. Ingarianti, and Z. A. Anwar, "Pengembangan model deteksi dini Anak Berkebutuhan Khusus (ABK) pada tingkat Pendidikan Anak Usia Dini (PAUD) di Kota Malang," J. Ilm. Psikol. Terap., vol. 4, no. 1, pp. 62-74, 2016.

[2] H. Haryanto, Diagnosis dan Asesmen Tumbuh Kembang Anak Berkebutuhan Khusus Usia Dini. Yogyakarta: Venus Gold Press, 2010.

[3] S. Sunardi and S. Sunaryo, Intervensi Dini Anak Berkebutuhan Khusus. Jakarta: Depdiknas, 2007.

[4] J. G. Nicholas and A. E. Geers, "Effects of early auditory experience on the spoken language of deaf children at 3 years of age," Ear Hear., vol. 27, no. 3, p. 286, 2006.

[5] C. S. Lidz, Early childhood Assessment. New Jersey: John Wiley \& Sons. Inc, 2003. 